\title{
Perencanaan Strategis Sistem Informasi Pada Bapelkes Provinsi Jambi Dengan TOGAF ADM
}

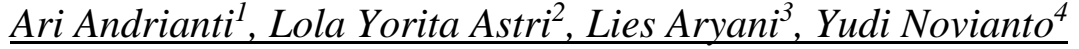 \\ Sistem Informasi, Fakultas Ilmu Komputer, Universitas Dinamika Bangsa \\ Jalan Jenderal Sudirman Thehok Jambi, Indonesia \\ ariandrianti@gmail.com ${ }^{1}$,astri0206@gmail.com ${ }^{2}$, liesaryani6@gmail.com ${ }^{3}$, yudinovianto@unama.com ${ }^{4}$
}

\begin{abstract}
Balai Pelatihan Kesehatan (Bapelkes) as an institution under the Health Office that has the task and function in improving human resources within the Jambi Provincial Health Office is currently not supported by an integrated information system, so that in carrying out daily activities it is only done manually in processing required data. Data processing still utilizes Microsoft Office Excel so that data is not collected in the same database. Each part of the UPTD itself has different excel files as well. Developing strategic planning for information systems is the goal of this study using the TOGAF ADM (Architecture Development Method) framework which consists of a preliminary phase, a requirements management phase, an architecture vision phase, a business architecture phase, an information system architecture phase and a technology architecture phase. This research produces blueprints for each phase of architecture at Bapelkes Jambi Province.
\end{abstract}

Keywords: strategic planning, togaf, architecture development method

\begin{abstract}
Abstrak
Balai Pelatihan Kesehatan (Bapelkes) sebagai institusi dibawah Dinas Kesehatan yang memiliki tugas dan fungsi dalam peningkatan sumber daya manusia di lingkungan Dinas Kesehatan Provinsi Jambi saat ini belum ditunjang dengan sistem informasi yang terintegrasi, sehingga dalam pelaksanaan kegiatan sehari-hari hanya dilakukan secara manual dalam mengolah data yang dibutuhkan. Pengolahan data masih memanfaatkan Microsoft Office Excel sehingga data tidak terkumpul dalam database yang sama. Setiap bagian dari UPTD ini sendiri memiliki file-file excel yang berbeda-beda juga. Menyusun perencanaan strategis sistem informasi merupakan tujuan dari penelitian ini dengan menggunakan kerangka kerja TOGAF ADM (Architecture Development Methode. Penelitian ini menghasilkan blueprint pada setiap fase arsitektur pada Bapelkes Provinsi Jambi.
\end{abstract}

Kata kunci : rencana strategis, togaf, architecture development method

\section{Pendahuluan}

Dinas Kesehatan tingkat provinsi sebagai bagian dari Departemen Kesehatan Republik Indonesia merupakan salah satu perangkat daerah, dalam rangka membantu gubernur untuk melaksanakan kegiatan urusan pemerintahan di bidang kesehatan. Pada struktur Dinas Kesehatan Provinsi Jambi terdapat beberapa bidang yang dibawahi oleh Kepala Dinas. Adapun bidang-bidang yang dimaksud antara lain: bidang kesehatan masyarakat, bidang pencegahan dan pengendalian penyakit, bidang pelayanan kesehatan, dan bidang sumberdaya kesehatan. Kesemua bidang tersebut ditunjang oleh beberapa Unit Pelaksana Teknis Daerah (UPTD) yang bertanggungjawab langsung kepada kepala dinas pada bagan struktur organisasi Dinas Kesehatan Provinsi Jambi [1].

UPTD Balai Pelatihan Kesehatan (Bapelkes) yang memiliki tugas dan fungsi dalam peningkatan sumber daya manusia di lingkungan Dinas Kesehatan Provinsi Jambi. Secara struktur organisasi, UPTD Balpekes ini diketuai oleh Ketua UPTD Bapelkes, berikutnya ada sub bagian Tata Usaha, seksi Pelatihan, seksi Pengendalian Mutu Pelatihan dan kelompok jabatan fungsional [2]. Dengan berbagai kegiatan yang bertujuan untuk meningkatkan kualitas sumber daya manusia di lingkungan Dinas Kesehatan baik untuk kabupaten maupun untuk Kota di Provinsi Jambi, maka UPTD ini dapat dipandang sebagai sebuah enterprise.

UPTD Bapelkes berkantor di Kelurahan Pijoan, Kec. Jambi Luar Kota, Kabupaten Muaro Jambi, Jambi. UPTD ini belum ditunjang dengan sistem informasi yang terintegrasi, sehingga dalam pelaksanaan kegiatan sehari-hari hanya dilakukan secara manual dalam mengolah data yang dibutuhkan. Untuk informasi UPTD ini sendiri, memang dapat diakses melalui sebuah laman website yang bersifat statik. 
Walaupun demikian, sangat disayangkan sekali website ini sendiri belum dibawah domain .go.id. Hanya mengandalkan domain free yang kredibilatasnya belum tentu baik. Untuk urusan internal, pengolahan data juga masih memanfaatkan Microsoft Office Excel sehingga data tidak terkumpul dalam database yang sama. Setiap bagian dari UPTD ini sendiri memiliki file-file excel yang berbeda-beda juga.

Oleh sebab itu, pada penelitian ini penulis akan membuat perencanaan strategis sistem informasi dengan memanfaatkan framework TOGAF ADM untuk UPTD Bapelkes. Dimana kerangka kerja ini merupakan suatu skema dan pengembangan metode serta standar untuk arsitektur enterprise yang digunakan sebagai panduan dalam membuat sistem informasi terintegrasi. TOGAF sebagai salah satu framework, memberikan mekanisme yang terperinci dalam menyusun dan menerapkan arsitektur enterprise serta sistem informasi yang disebut dengan ADM. Architecture Development Method (ADM) merupakan metode internal yang berisikan aktivitas-aktivitas yang digunakan dalam menggambarkan pengembangan arsitektur enterprise [3].

TOGAF ADM adalah kerangka dan metode yang mampu mendukung terhadap strategi dan keselarasan [4]. Pada penelitian terdahulu, perencanaan strategi ini dapat menghasilkan solusi bagi proses bisnis organisasi [5][6][7]. Berdasarkan penelitian yang dilakukan oleh Nela et.al, matangnya perencanaan strategis pada sebuah organisasi dapat mengoptimalkan layanan yang diberikan [8]. Sementara merujuk pada penelitian Virna et.al dalam menyusun perencanaan strategis sistem informasi sangat dibutuhkan suatu kerangka kerja yang menjadi acuan agar dapat mengelola sistem yang rumit dan kompleks serta menyelaraskan bisnis dengan teknologi informasi yang akan dikembangkan [9].

\section{Metodologi}

Kerangka kerja penelitian penelitian ini adalah sebagai berikut (mengacu kepada framework TOGAF ADM) [10]:

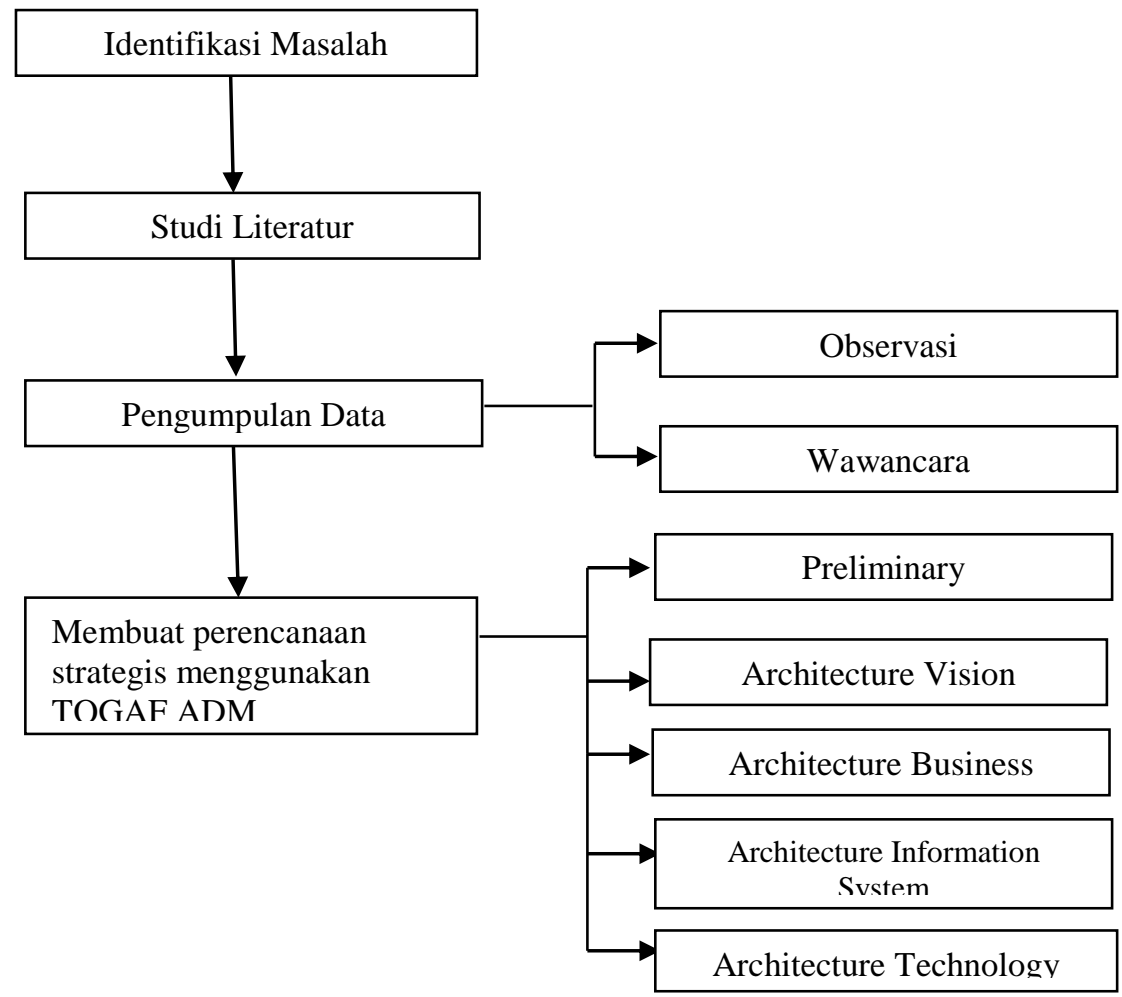

Gambar 1. Kerangka Kerja Penelitian 
Berikut ini pembahasan tahapan diatas:

1. Identifikasi Masalah

Penelitian ini diawali dengan menemukan permasalahan yang terjadi kemudian merumuskan masalah yang ada pada UPTD Bapelkes Provinsi Jambi. Dengan adanya pengidentifikasian masalah, maka penelitian akan menjadi jelas dan terarah.

2. Studi Literatur

Tahap ini merupakan proses yang dilakukan oleh peneliti untuk mengumpulkan berbagai literasi kemudian mempelajari dan memahami konsep dan teori yang berhubungan dengan topik yang diangkat atau permasalahan yang sedang diteliti. Informasi tersebut diperoleh dari berbagai buku, jurnal, dan internet.

3. Pengumpulan Data

Tahapan pengumpulan data bertujuan untuk mendapatkan data dan informasi mengenai kondisi saat ini sistem yang berjalan pada UPTD Bapelkes Provinsi Jambi. Dalam pelaksanaan dan penulisan ilmiah penelitian ini menggunakan beberapa pola pengumpulan data yang dapat dilakukan dengan dua cara yaitu:

a. Pengamatan (Observation)

Penelitian dengan metode observasi ini dilakukan dengan mendatangi UPTD Bapelkes secara langsung yang bertujuan untuk memperkuat data, mengetahui serta mendapatkan informasi secara langsung.

b. Wawancara (Interview)

Penulis melakukan kegiatan wawancara secara langsung terhadap pimpinan dan pihak - pihak yang terkait untuk mendapatkan informasi yang dibutuhkan, sehingga penulis mengetahui permasalahan-permasalahan yang terjadi dan mempermudah dalam memperoleh penyelesaian untuk mengembangkan sistem tersebut.

4. Membuat Perencanaan arsitektur sistem informasi dengan menggunakan TOGAF ADM

a. Preliminary

Fase preliminary merupakan sesi atau langkah yang bertujuan menyakinkan para pemangku kepentingan yang terlibat dalam proses perancangan arsitektur informasi untuk mensukseskan proses arsitektur dari awal hingga akhir

b. Fase Arsitektur Vision

Fase ini digunakan untuk mendefinisikan ruang lingkup dan visi arsitektur secara keseluruhan meliputi profil organisasi, pendefinisian visi dan misi, tujuan organisasi

c. Fase Arsitektur bisnis

Pada fase ini dilakukan proses pendefinisian kondisi saat ini arsitektur bisnis, kemudian menentukan model bisnis yang diinginkan berdasarkan proses bisnis yang terjadi. Pada tahapan ini mendefinisikan area bisnis dan stakeholder.

d. Fase Information System Architecture

Pada fase ini dibagi menjadi dua proses yaitu proses penggambaran arsitektur data dan arsitektur aplikasi. Pada tahapan ini menentukan kebutuhan data dalam membuat arsitektur data dan aplikasi pada UPTD Bapelkes Provinsi Jambi.

e. Fase Technology Architecture

Pada fase ini dilakukan proses untuk memodelkan arsitektur teknologi yang ditargetkan, dengan menentukan tipe teknologi yang akan digunakan dengan menggunakan Technology Portofolio Catalog. Dalam tahapan ini juga dilakukan peninjauan terhadap pilihan-pilihan yang diperlukan dalam pemilihan teknologi.

\section{Hasil dan Pembahasan \\ 3.1 Preliminary Phase}

Pada fase ini merupakan tahap permulaan dengan melakukan aktivitas persiapan perencanaan strategis sistem informasi. Tahap ini menentukan bagaimana arsitektur enterprise akan dibuat dan dilaksanakan. Langkah yang dilakukan adalah mengidentifikasi $5 \mathrm{~W}+1 \mathrm{H}$ untuk perencanaan strategis sistem informasi di Bapelkes Provinsi Jambi. Tujuan dari proses identifikasi ini adalah untuk mengetahui objek-objek yang akan terlibat dalam menyusun arsitektur ini. 
Tabel 1. Identifikasi $5 W+1 H$

\begin{tabular}{|c|c|c|}
\hline No. & Driver & Deskripsi \\
\hline 1. & What & $\begin{array}{l}\text { Objek: Lingkup Arsitektur } \\
\text { Deskripsi: Membuat Perencanaan Strategis Sistem Informasi Pada } \\
\text { Bapelkes Provinsi Jambi Dengan Togaf Adm }\end{array}$ \\
\hline 2. & Who & $\begin{array}{l}\text { Objek: Siapa yang memodelkan dan yang bertanggung jawab } \\
\text { Deskripsi: } \\
\text { Pembuat Perencanaan dan penanggung jawab: Tim Peneliti }\end{array}$ \\
\hline 3. & Where & $\begin{array}{l}\text { Objek: Lokasi objek penelitian } \\
\text { Deskripsi: Bapelkes Provinsi Jambi } \\
\text { Pijoan, Kec.Jambi Luar Kota Kabupaten Muaro Jambi }\end{array}$ \\
\hline 4. & When & Objek:Waktu Penyelesaian \\
\hline 5. & Why & $\begin{array}{l}\text { Objek: Mengapa perencanaan strategis sistem informasi ini dibuat } \\
\text { Deskrispi: untuk menyelaraskan teknologi yang digunakan dengan } \\
\text { strategi bisnis organisasi. Katalog dan diagram arsitektur untuk } \\
\text { menghasilkan cetak biru dan pemetaan aplikasi. }\end{array}$ \\
\hline 6. & How & $\begin{array}{l}\text { Objek: Menentukan bagaimana rancangan dibuat } \\
\text { Deskripsi: Rancangan dibuat menggunakan framework TOGAF ADM }\end{array}$ \\
\hline
\end{tabular}

\subsection{Requirements Management}

Tabel berikut berisikan tentang permasalahan pada objek yang dapat didukung dengan sistem informasi:

Tabel 2. Permasalahan dalam Aktivitas Organisasi

\begin{tabular}{|c|c|c|}
\hline No & Aktivitas & Permasalahan \\
\hline 1. & Perencanaan Pelatihan & $\begin{array}{l}\text { - adanya ketidaksesuain antara pelatihan yang akan } \\
\text { dibuat dengan kurikulum yang ditetapkan oleh } \\
\text { kemenkes } \\
\text { - ketidaksesuaian jadwal pelaksanaan pelatihan dengan } \\
\text { kalender pelatihan yang telah ditetapkan. }\end{array}$ \\
\hline 2. & Pelaksanaan Pelatihan & $\begin{array}{l}\text { - Infrastruktur yang tersedia belum memadai untuk } \\
\text { menjalankan kegiatan belajar melalui blended learning }\end{array}$ \\
\hline 3. & Rekapitulasi Data Pelatihan & $\begin{array}{l}\text { - Kesulitan untuk melakukan proses perekapan dan } \\
\text { pengolahan data widyaswara pelatihan, data peserta } \\
\text { pelatihan dan bahan ajar pelatihan secara periodik } \\
\text { - Belum dikembangkannya sistem khusus untuk } \\
\text { merekap data-data pelatihan } \\
\text { - Belum ada Proses pengorganisasian data dengan baik }\end{array}$ \\
\hline 4. & Pembuatan laporan & $\begin{array}{l}\text { - Masih sering terjadi kesalahan dalam pembuatan } \\
\text { laporan data peserta pelatihan } \\
\text { - Salah dalam pengetikan dan penyusunan laporan }\end{array}$ \\
\hline 5. & Keuangan & $\begin{array}{l}\text { - Proses pencatatan data keuangan masih bersifat manual } \\
\text { - Laporan yang lambat dan tidak akurat }\end{array}$ \\
\hline
\end{tabular}




\subsection{Archtecture Vision}

Pada fase ini mengutamakan proses identifikasi visi dari perencanaan strategis SI/TI yang dilakukan dengan meninjau dokumen-dokumen yang berisi visi, tugas, dan fungsi organisasi dalam hal ini Bapelkes Provinsi Jambi bertujuan untuk mendefinisikan kebutuhan SI/TI yang diperlukan untuk mendukung aktivitas bisnis UPTD Bapelkes Provinsi Jambi

Visi dari Bapelkes Provinsi Jambi adalah terciptanya pelatihan yang bermutu dalam Pengembangan Profesionalisme SDM Kesehatan untuk mewujudkan Jambi Tuntas 2021. Adapun misi dari Bapelkes Provinsi Jambi adalah

1. Mewujudkan diklat bidang kesehatan yang terakreditasi

2. Mengembangkan SDM Kesehatan melalui diklat

3. Mewujudkan sarana dan prasarana diklat terstandar

Analisis rantai nilai bertujuan mengklasifikasikan seluruh aktivitas yang ada pada Bapelkes Provinsi Jambi. Klasifikasi aktivitas dalam analisis rantai nilai terbagi menjadi dua bagian, yaitu aktivitas utama dan aktivitas pendukung.

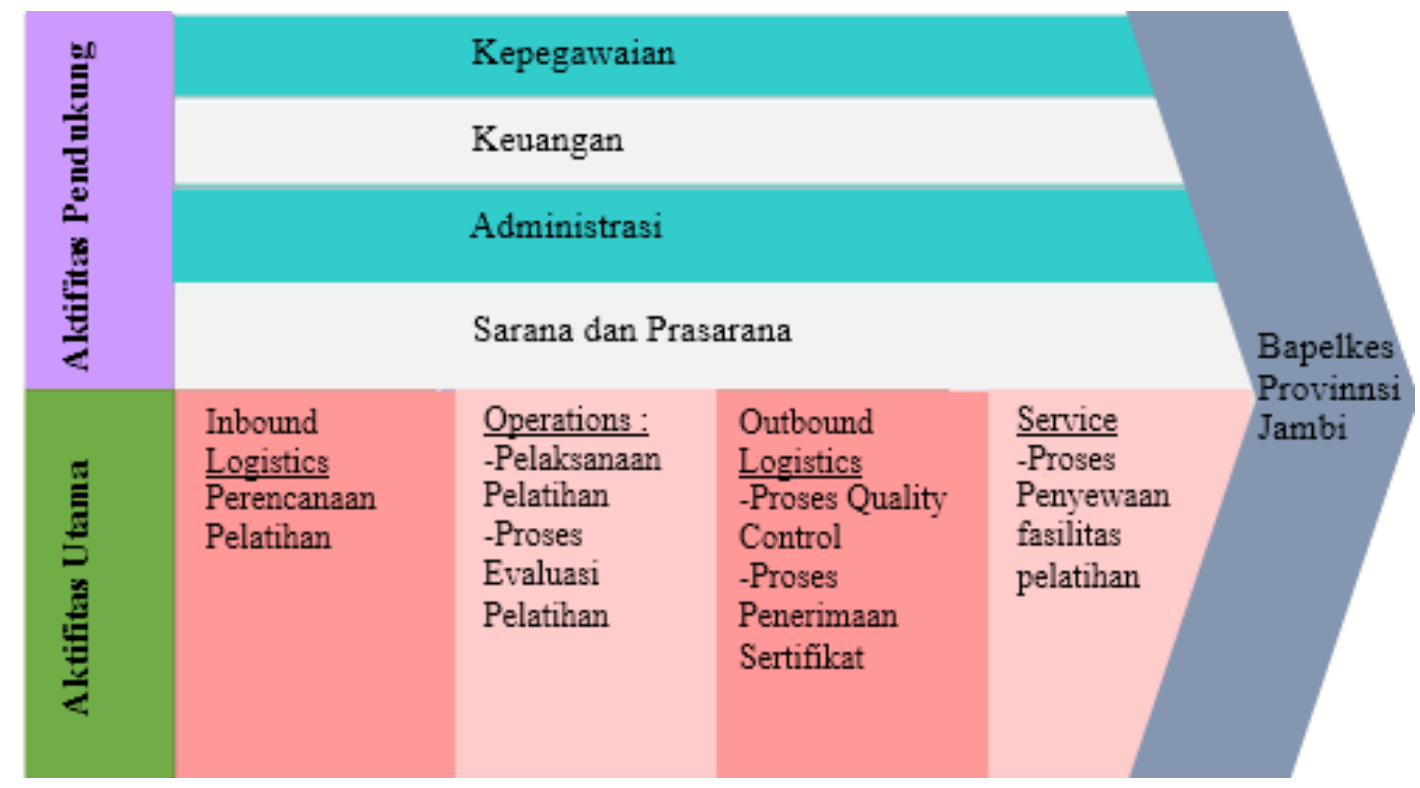

Gambar 2 Analisis Value Chain

\subsection{Business Architecture}

Rancangan arsitektur bisnis dirancang dalam bentuk bpmn (business process model and notation) untuk masing-masing aktivitas di Bapelkes Provinsi Jambi, rancangan arsitektur bisnis dapat dilihat pada gambar berikut ini:

1. Rancangan Arsitektur Bisnis Perencanaan Pelatihan

Pada gambar dibawah ini dapat dilihat proses bisnis pada sistem perencanaan pelatihan. Sistem ini melibatkan tiga actor antara lain seksi pelatihan, dinas kesehatan dan sub bagian tata usaha. 


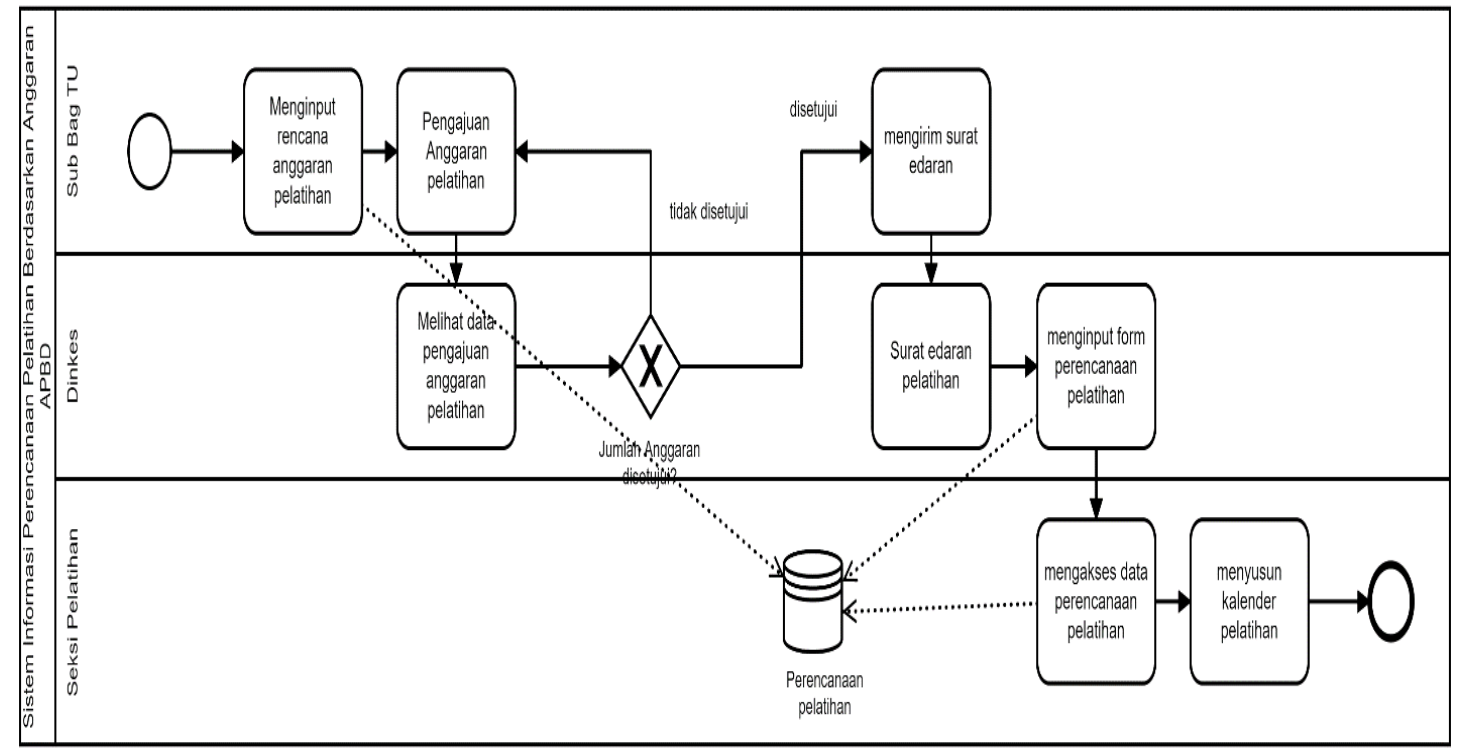

Gambar 3 Rancangan Arsitektur Bisnis Perencanaan Pelatihan

2. Rancangan Arsitektur Bisnis Pelaksanaan dan Evaluasi Pelatihan

Pada gambar dibawah ini adalah proses bisnis pada pelaksanaan dan evaluasi pelatihan. Actor yang terlibat dalam sistem ini adalah peserta pelatihan yaitu tenaga kesehatan, dinas kesehatan, seksi pelatihan, widyaswara dan seksi pengendalai mutu.

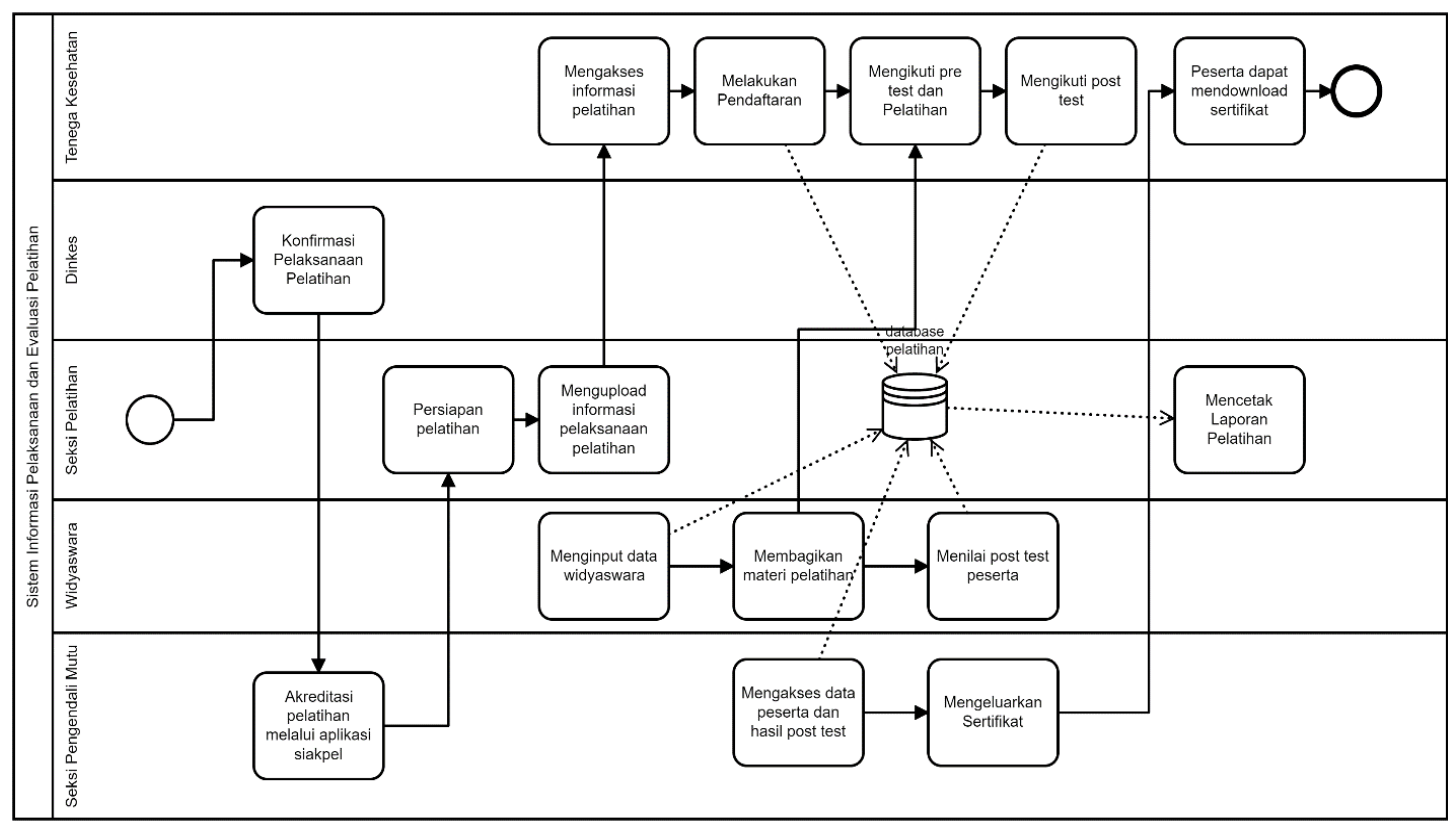

Gambar 4 Rancangan Arsitektur Bisnis Pelaksanaan dan Evaluasi Pelatihan

\subsection{Information System Architectures}

Aktifitas yang dilakukan pada fase ini lebih mengutamakan pada proses pengembangan arsitektur data dan aplikasi. Arsitektur sistem informasi dalam tahapan ini meliputi arsitektur data yang mendefinisikan data-data yang digunakan untuk kebutuhan fungsi bisnis, proses bisnis dan layanan yang ada pada UPTD Bapelkes Provinsi Jambi sedangkan arsitektur aplikasi mendefinisikan aplikasi apa saja yang akan digunakan oleh organisasi. 


\subsubsection{Application Architecture}

Dalam membuat rancangan arsitektur aplikasi untuk Bapelkes Provinsi Jambi, akan digunakan tools use case diagram. Diagram ini berguna untuk melihat interaksi aktor dengan sistem.

1. Aplikasi Perencanaan Pelatihan

Arsitektur aplikasi perencanaan pelatihan memiliki 4 aktor dan 10 usecase yang dapat dilakukan dalam sistem perencanaan pelatihan. Aktornya yaitu sub bagian tata usaha, dinas kesehatan, seksi pelatihan dan kepala bapelkes

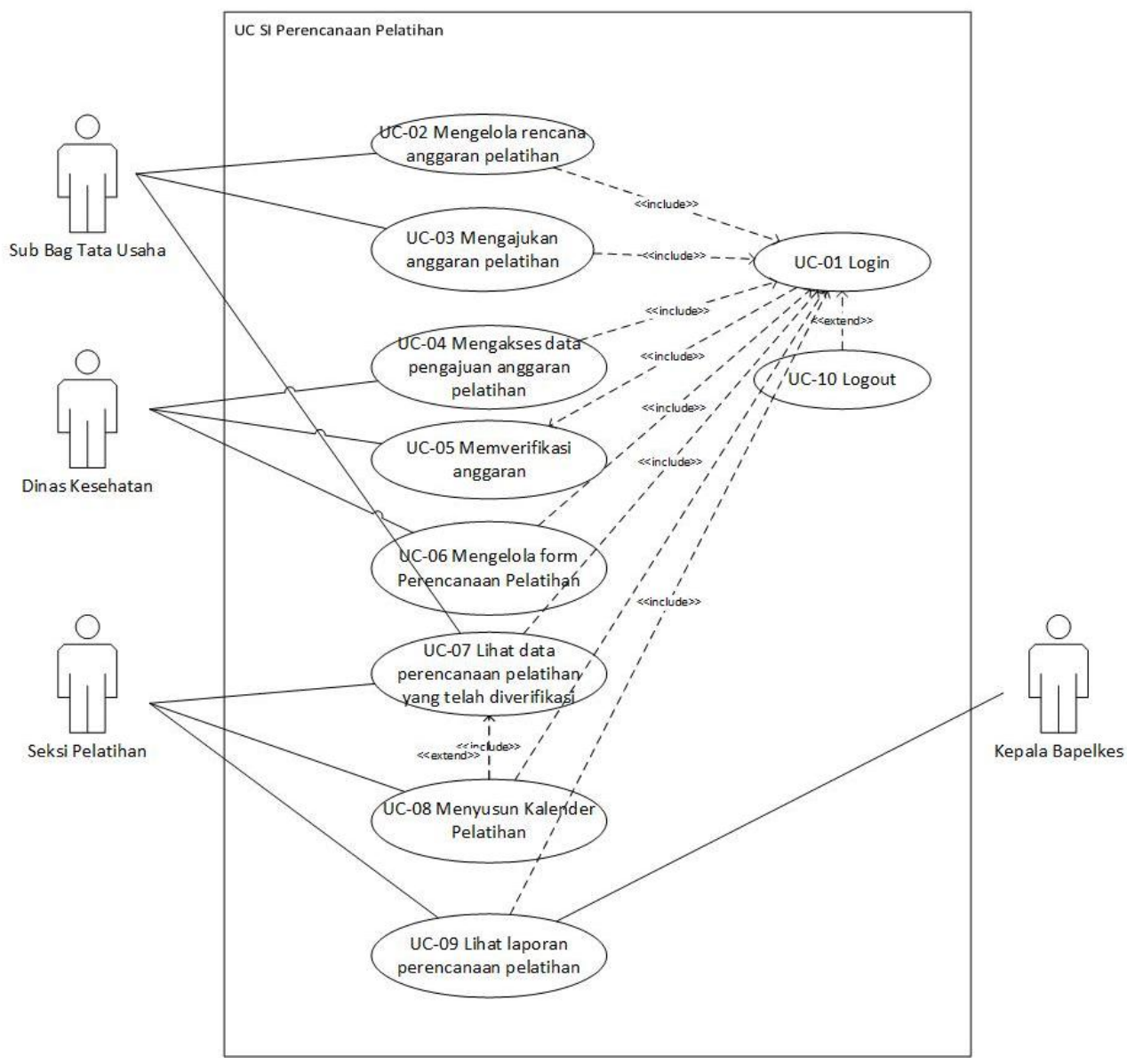

Gambar 5 Arsitektur Aplikasi Perencanaan Pelatihan

\subsubsection{Data Architecture}

Arsitektur ini digambarkan dengan menggunakan tools data dissemination diagram dan class diagram.

\section{Data Disemination Diagram}

Pada gambar dibawah ini menggambarkan hubungan layanan Bapelkes Provinsi Jambi, Aplikasi dan Data. Di aplikasi perencanaan pelatihan terdapat data anggaran pelatihan, panitia pelatihan, dan kalender pelatihan. Di aplikasi learning management system terdapat data peserta, data pre test, data post test, data pelatihan dan data widyaswara. Pada aplikasi pengolahan data pengendalian mutu terdapat data quality control dan data saran perbaikan. Pada aplikasi pengolahan data penyewaan fasilitas pelatihan terdapat data fasilitas pelatihan dan data penyewaan. 


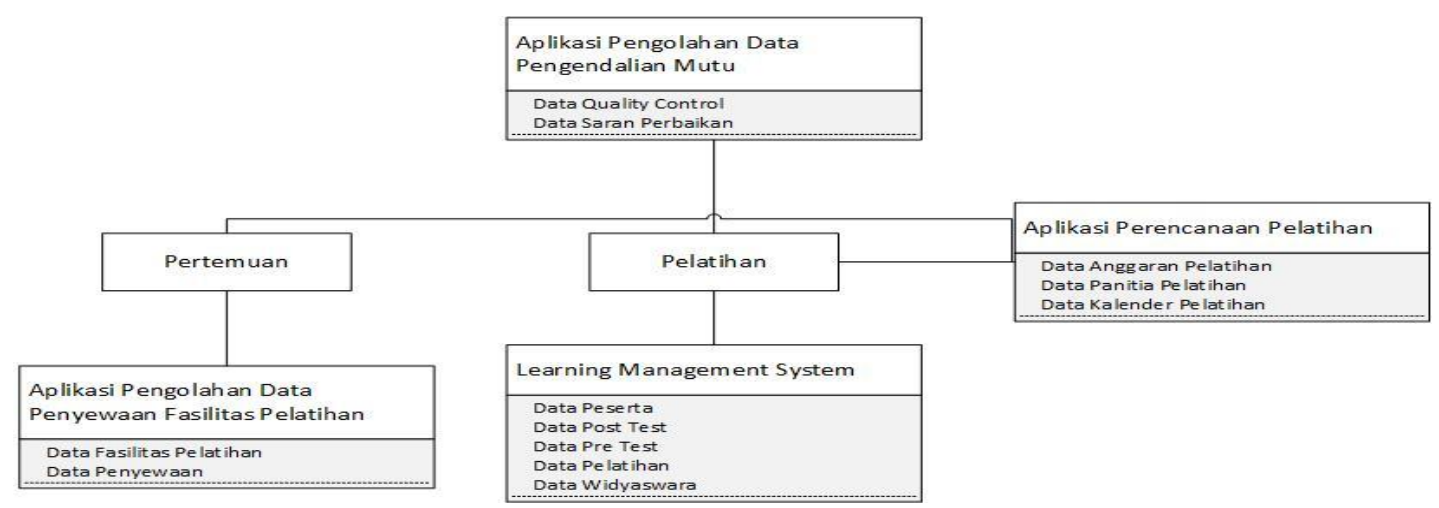

Gambar 6 Data Disemination Diagram

\section{Class Diagram}

Diagram ini bermanfaat untuk melihat hubungan antar kelas pada sistem sehingga dapat mengidentifikasi kebutuhan data untuk rancangan basisdata.

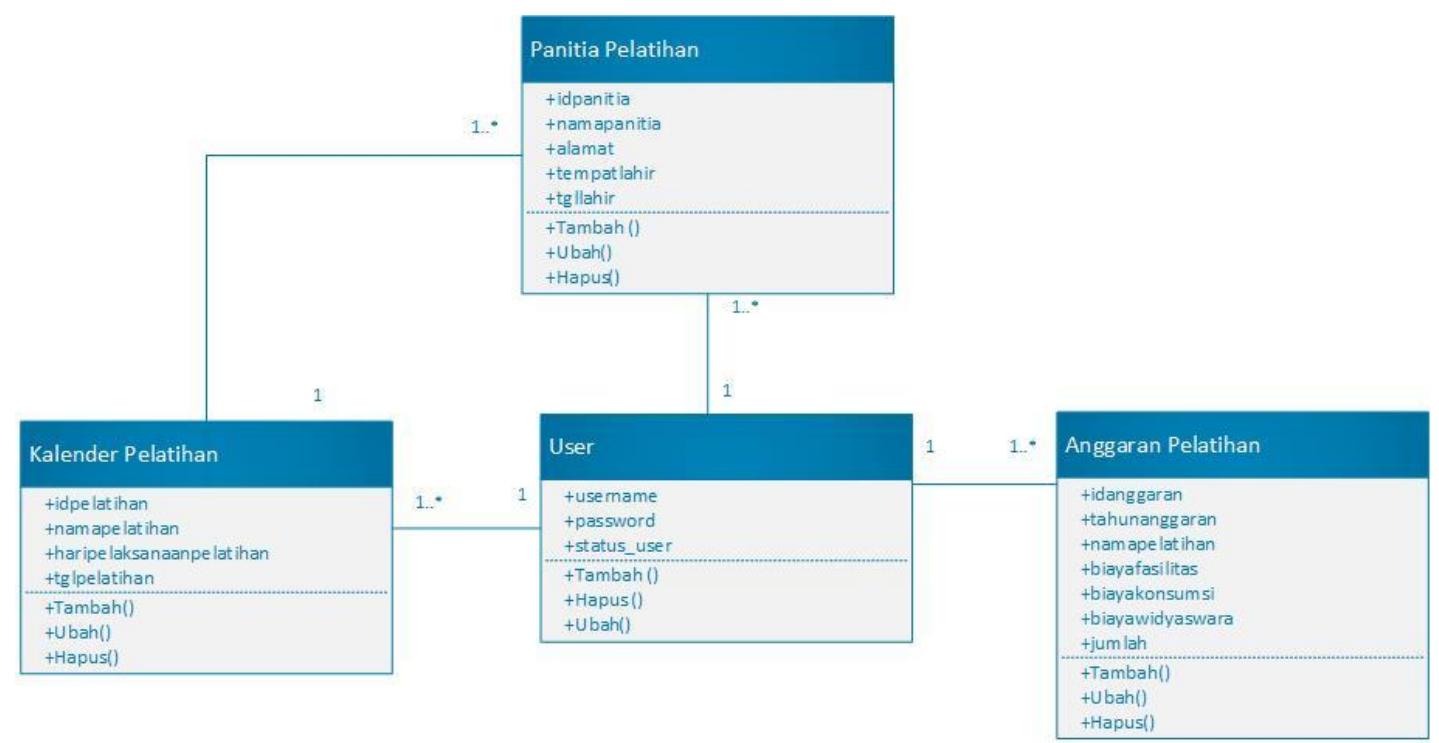

Gambar 7 Class Diagram

\subsection{Technology Architecture}

3.6.1 Konfigurasi Jaringan Internal

Pada gambar dibawah ini menggambarkan jaringan usulan pada Bapelkes Provinsi Jambi. Jaringan terhubung menggunakan switch dan wireless. Diikuti dengan disaster recovery center yang terhubung melalui router untuk backup data. 


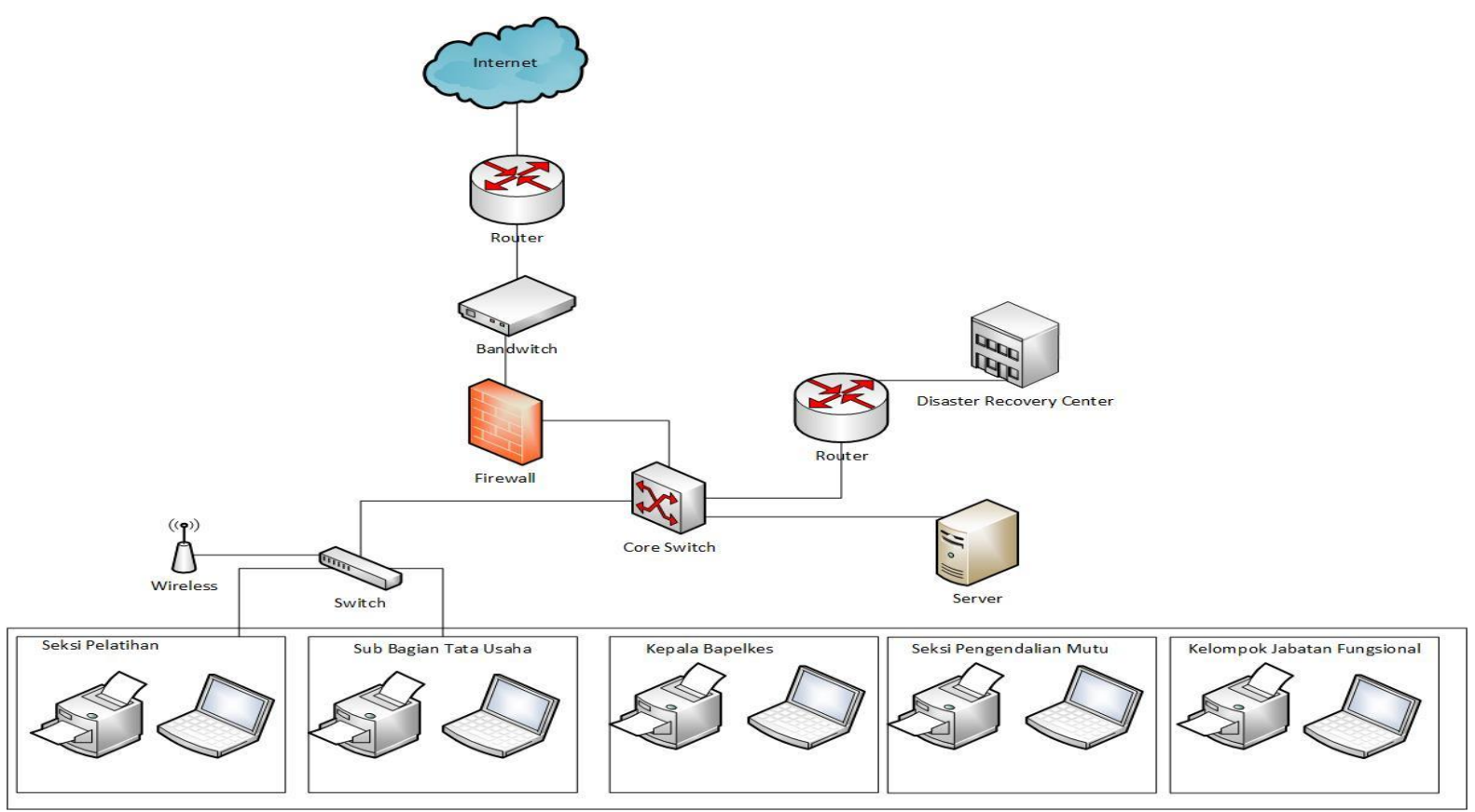

Gambar 8. Arsitektur Jaringan Usulan

\subsubsection{Platform Decomposition Diagram}

Berfungsi untuk menggambarkan sistem ulasan yang bersifat menyeluruh

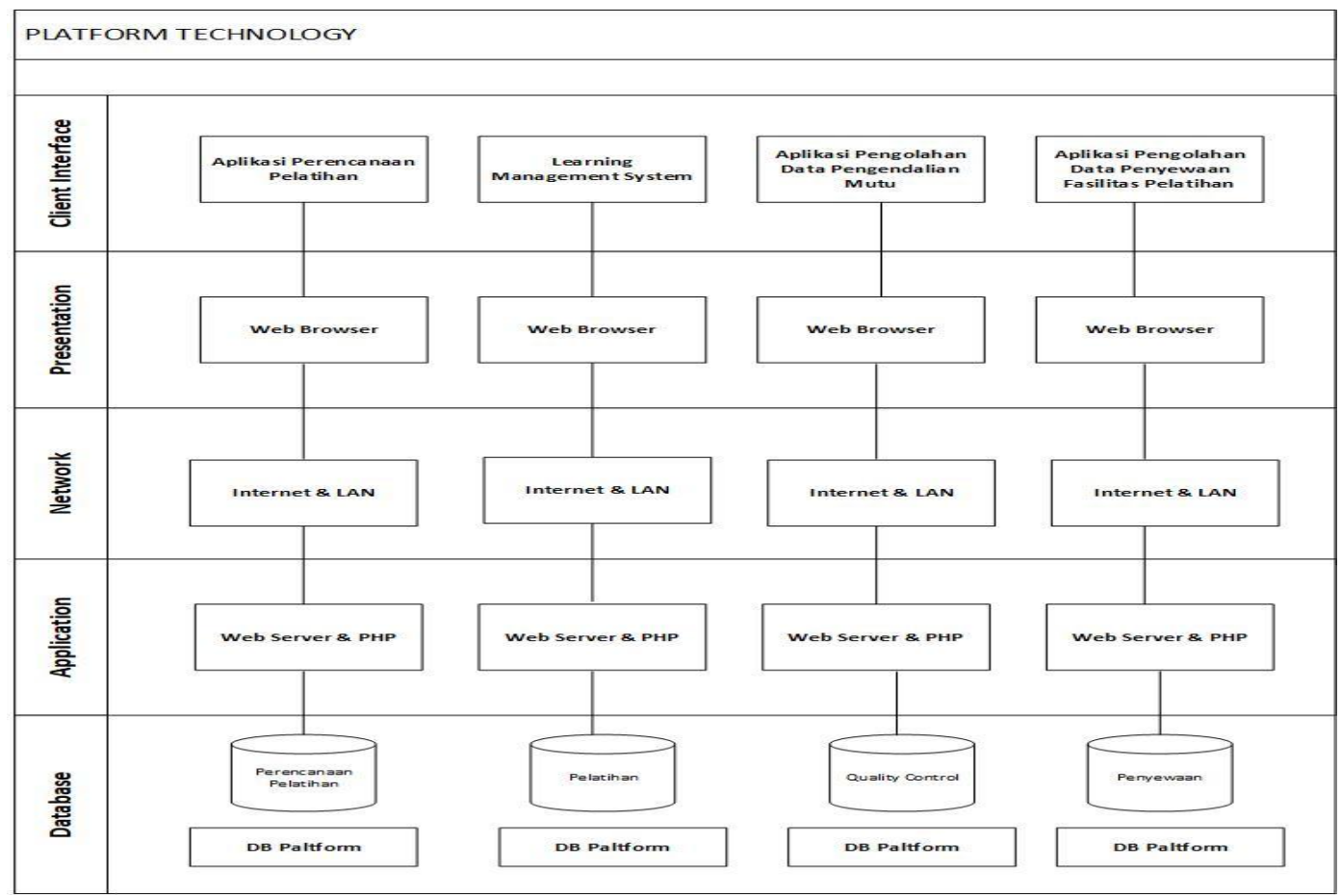

Gambar 9. Platform Technology 


\section{Kesimpulan}

Dengan menggunakan framework ini, Bapelkes telah memiliki 4 Kandidat sistem informasi tersebut yaitu aplikasi perencanaan pelatihan, learning management system, aplikasi pengolahan data pengendalian mutu dan aplikasi pengolahan data penyewaan fasilitas pelatihan. Dimana nantinya dapat dijadikan acuan dalam mengembangkan SI/TI terintegrasi.

\section{Daftar Pustaka}

[1] Peraturan Gubernur Jambi Nomor 36, "Peraturan Gubernur Jambi Nomor 36 Tahun 2016 Tentang Kedudukan, Susunan Organisasi, Tugas Dan Fungsi, Serta Tata Kerja Dinas Kesehatan Provinsi Jambi," pp. 1-25, 2016.

[2] Pergub, "Peraturan Gubernur Jambi Nomor 23 Tahun 2018 Tentang Kedudukan, Susunan Organisasi, Tugas Dan Fungsi, Serta Tata Kerja UPTD Bapelkes Provinsi Jambi,” pp. 1-16, 2018.

[3] The-Open-Group, TOGAF® Version 9.1 , vol. Document N. 2011.

[4] B. Rouhani, M. Mahrin, F. Nikpay, and P. Nikfard, "A Framework for Evaluation of Enterprise Architecture Implementation Methodologies,” Jurnalteknologi.Utm.My, vol. 9, no. 1, pp. 1-6, 2014.

[5] L. Rahmadi, E. Utami, A. Amborowati, and M. T. Informatika, "Perencanaan Strategi Sistem Informasi Untuk," vol. 7, no. 2, pp. 6-8, 2015.

[6] I. Hizbullah and M. Salmin, "Perencanaan Strategis Sistem Informasi / Teknologi Informasi menggunakan Framework TOGAF pada Dinas Pariwisata Kabupaten Pulau Morotai Framework at the Morotai Island District Tourism Office," vol. x, no. 30, pp. 1-6, 2018, doi: 10.34148/teknika.v10i2.355.

[7] A. Mualo and A. D. Budiyanto, "Perencanaan Strategis Sistem Informasi Menggunakan Togaf (Studi Kasus: Universitas Satria Makassar)," Semin. Ris. Teknol. Inf. tahun 2016, pp. 294-304, 2016.

[8] N. Rizky and A. F. Firmansyah, "PERENCANAAN ARSITEKTUR ENTERPRISE MENGGUNAKAN TOGAF ADM VERSI 9 ( Studi Kasus: Bimbel Salemba Group )," Stud. Inform. J. Sist. Inf., vol. 10, no. 1, pp. 11-20, 2017.

[9] V. Soraya and W. S. Sari, "Perancangan Enterprise Architecture Sistem Informasi dengan Menggunakan Framework TOGAF ADM pada CV. Garam Cemerlang," JOINS (Journal Inf. Syst., vol. 4, no. 2, pp. 148-156, 2019, doi: 10.33633/joins.v4i2.3054.

[10] S. Kotusev, "TOGAF-based enterprise architecture practice: An exploratory case study," Commun. Assoc. Inf. Syst., vol. 43, no. 1, pp. 321-359, 2018, doi: 10.17705/1CAIS.04320. 